\title{
CASE STUDY OF DELAY CONSTRUCTION PROJECTS IN BIDAU DILI TIMOR-LESTE BRIDGE
}

\author{
Eliseu Soares Pererira Amaral \\ eliseupereiraamara195@gmail.com \\ Civil engineering and planning \\ Civil Engineering \\ Narotama University Surabaya
}

\begin{abstract}
The process of implementing development projects has many obstacles that were not predicted beforehand resulting in delays in project completion which have an impact on increasing the cost of project implementation. sometimes the project is not completed in accordance with a predetermined schedule that may be caused by certain factors. Various ways can be done to anticipate and be a solution to the delay. The purpose of the study is to analyze the factors that influence delays in bridge construction projects in Bidau Timor - Leste and how to anticipate delays in project work. The research method used is descriptive method by observation and direct interviews. So that there are several dominant factors that influence the delay of the Bidau Timor-Leste bridge construction project, including the types of weather, material and financial. To anticipate delays in construction projects, it is necessary to do a work contract in accordance with the contract law in which all matters are regulated, so that the anticipation, mitigation and accountability are clear. Identification of the application of overcoming delays in the Bidau TimorLeste bridge construction project if viewed from the side of the existing contract there are still shortcomings, so it needs to be improved in terms of working contract documents and refer to the contract law.
\end{abstract}

Keywords: Delay Factors, Bridge Construction, Employment Contracts.

\section{INTRODUCTION}

\section{Research Background}

The Democratic Republic of Timor-Leste is a new country that is still in the period of regional development because it does not yet have the infrastructure, buildings and bridges to create prosperity and prosperity for the people of Timor-Leste.

Delay in project completion does not only occur in government-owned projects but also in private projects. The development of construction projects that is increasing has given birth to service companies in the construction sector. The success of a construction project can be measured in two ways, namely the benefits and the timeliness of completion (Desharyanto and Fansuri, 2013).

Based on case studies of a number of bridge construction projects in Dili, TimorLeste, most have experienced delays in its completion due to several factors. Various ways can be done to anticipate and be a solution to the delay. However, delays still occur frequently, therefore in this study the author wants to conduct a case study of the factors that cause delays, the role of legislation in responding to delays in construction projects and the implementation of delays in delaying construction projects in Dili Timor-Leste. contract or according to the contract document. The research is titled "Case Study of Delay Bridge Construction Projects in Dili Timor-Leste"

Based on the background described above, the following problem is formulated:

1. What factors influence the delay in bridge construction projects?

2. What is the role of the law in responding to bridge construction projects?

3. How is the implementation of countermeasures for delays in bridge construction projects in Bidau Dili Timor-Leste. 
Volume 03 Number 01 September 2019

East Timor is a new country with an age of independence approaching 17 years. internationally declared to be a small country separated from Indonesia in 2002. Timor Leste has a total area of $14,600 \mathrm{Km}^{2}$ which is mostly comprised of mountainous areas. East Timor has a population of 1.1 million where around $75 \%$ of them live in the capital city of Dili, the rest are scattered in the district.

\section{Understanding Project Delay.}

Project delays are time during which a part of the construction project is extended or not carried out in accordance with agreed agreements (according to Callahan et al 1992). According to Levis and Atherley (1996), if a job has been targeted to be completed at a specified time but for some reason cannot be fulfilled then it can be said the work is experiencing delays.

\section{Overcoming Late}

According to Istimawan Dipohusodo (1996), during the construction process there were always symptoms of periodic scarcity of the materials treated, in the form of basic materials or finished goods both locally and imported. How to control tardiness is;

a) Exert additional resources

b) Remove obstacles, or other efforts to ensure that work increases and bring it back to the plan line.

c) If it is not possible to stay on the original plan line it may be necessary to revise the schedule, which will then be used as a basis for evaluating the progress of work in the next moment. According to Agus Ahyari (1987), in order to overcome the material delays that occur because suppliers have experienced something, it is necessary to have a backup supplier. In preparing the supplier priority list, it is not enough to be compiled and used later. The list must be held every period of the evaluation of the usual supplier based on the relationship in the past.

\section{Factors that influence the construction project delay}

According to research conducted by (Wirabakti et. Al ..., 2014) delays in completion of work are based on several factors including labor, materials, managerial place characteristics, equipment, finance, physical building, design, weather, unexpected events and government policies. Here the authors describe the factors above in the form of theoretical mappping, following an explanation of several researchers who agree:

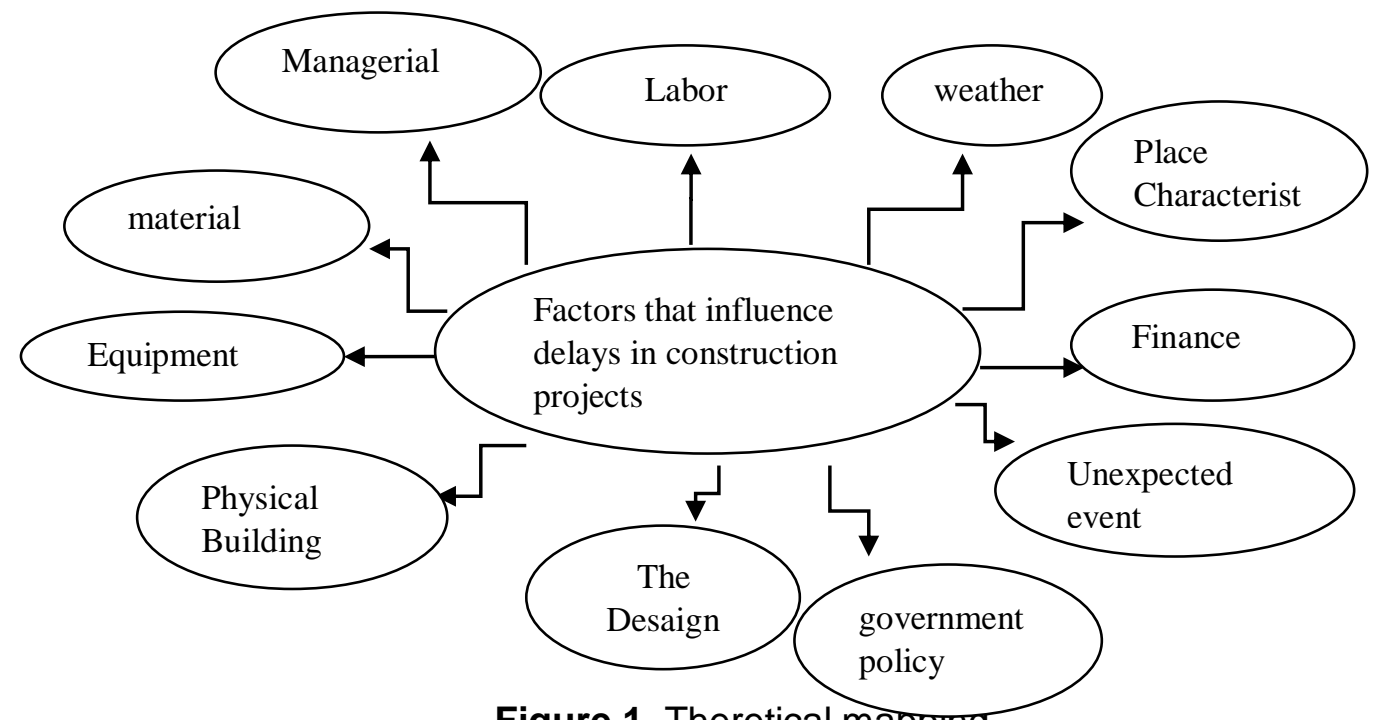

Figure 1. Theretical mappring 
Volume 03 Number 01 September 2019

\section{RESEARCH METHODOLOGY}

\section{Types of research}

In this research, the writer uses the Naturalistic / Qualitative method, because the formulation of the problem is still unclear and complex.

\section{Data collection techniques or data collection}

From the collection of interview data collected from sources, namely the open distribution of questionnaires from the government and the private sector, the total respondents of the two parties totaled 100 respondents, from the government 47 respondents and 53 private respondents.

\section{Data analysis.}

The explanation is as follows:

\section{Data Reduction}

Reducing data means summarizing choosing the main things, focusing on the things that are important, looking for themes and patterns (Sugiyono, 2014: 247).

\section{Data Display}

In qualitative research, the presentation of data can be done in the form of brief descriptions, charts, relationships between categories, flowcharts, and the like (Sugiyono, 2014: 247).

\section{Conclussions / Verifying (drawing conclusions)}

Conclusions in qualitative research are new findings that have never before existed. The findings can be in the form of a description or description of an object that was previously still dim or dark so that after being examined it becomes clear (Sugitono, 2014: 247).

\section{ANALYSIS AND DISCUSSION}

Table 1. Field Notes 1 (Private and Government)

\begin{tabular}{ccc}
\hline No. & Respondent & Remarks Answer No.1 \\
\hline 1 & $\begin{array}{c}47 \text { Respondents } \\
\text { (Government) }\end{array}$ & Delayed \\
2 & $\begin{array}{c}53 \text { Respondents } \\
\text { (Private) }\end{array}$ & Delayed \\
& & \\
\hline
\end{tabular}

From the above data it is known that the total total respondents both from the government and private parties amounted to 100 respondents. The percentage of $100 \%$ states this and can be seen in the diagram below : 
Volume 03 Number 01 September 2019

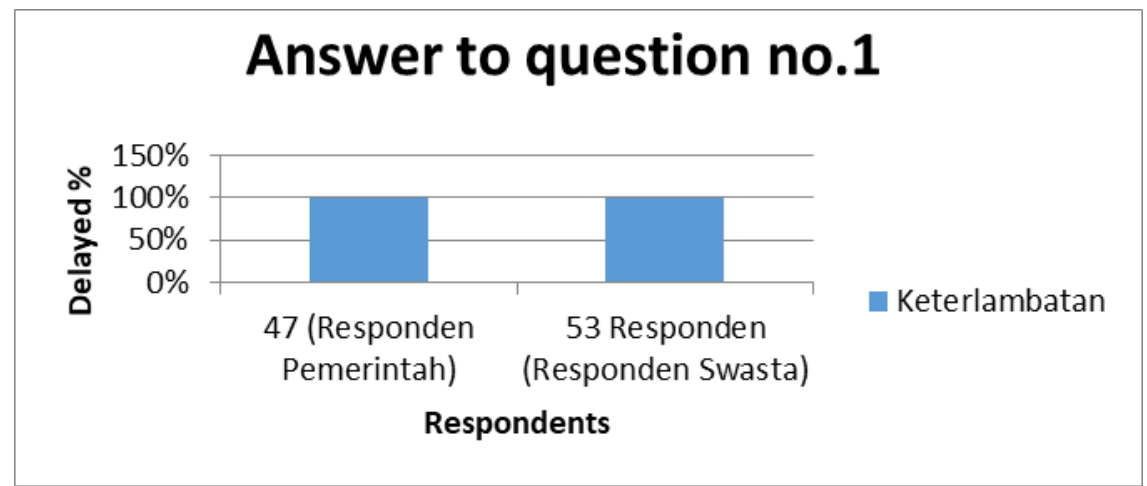

4.3 Percentage of late answers from all respondents.

(Source: research results, 2019)

In field note 2, the scope of this government project, an explanation of the factors influencing delays in construction projects in general from 47 interviewees having the same answers / statements can be seen in table 4.3 above. This record data is still very complex, because the types of questions are still in general, so the informants also gave statements in general and a broad scope.

\section{SPSS Factor Analysis}

\section{Factor Extraction}

Table 2. Government Factor Extraction Results

\begin{tabular}{|c|c|c|c|}
\hline \multirow[b]{2}{*}{ Component } & \multicolumn{3}{|c|}{ Initial Eigenvalues } \\
\hline & Total & $\begin{array}{c}\% \text { of } \\
\text { Variance }\end{array}$ & Cumulative \% \\
\hline 1 & 1,115 & 5,867 & 5,867 \\
\hline 2 & 1,093 & 5,753 & 11,620 \\
\hline 3 & 1,093 & 5,753 & 17,373 \\
\hline 4 & 1,093 & 5,753 & 23,126 \\
\hline 5 & 1,080 & 5,684 & 28,809 \\
\hline 6 & 1,068 & 5,622 & 34,431 \\
\hline 7 & 1,068 & 5,622 & 40,053 \\
\hline 8 & 1,068 & 5,622 & 45,675 \\
\hline 9 & 1,052 & 5,538 & 51,214 \\
\hline 10 & 1,044 & 5,497 & 56,711 \\
\hline 11 & 1,044 & 5,497 & 62,208 \\
\hline 12 & 1,044 & 5,497 & 67,705 \\
\hline 13 & 1,027 & 5,407 & 73,112 \\
\hline 14 & 1,022 & 5,378 & 78,490 \\
\hline
\end{tabular}


Volume 03 Number 01 September 2019

\begin{tabular}{cccc}
\hline 15 & 1,022 & 5,378 & 83,867 \\
16 & 1,022 & 5,378 & 89,245 \\
17 & 1,022 & 5,378 & 94,622 \\
18 & 1,022 & 5,378 & 100,000 \\
19 & $\begin{array}{c}6,133 \mathrm{E}- \\
016\end{array}$ & $3,228 \mathrm{E}-015$ & 100,000 \\
\hline
\end{tabular}

From Table 2 there are 18 components that have an eigenvalue above one, which means 18 factors are considered the most.

Table 3. Results of Extraction of Private Factors

\begin{tabular}{|c|c|c|c|}
\hline \multirow[b]{2}{*}{ Component } & \multicolumn{3}{|c|}{ Initial Eigenvalues } \\
\hline & Total & $\begin{array}{c}\% \text { of } \\
\text { Variance }\end{array}$ & Cumulative \% \\
\hline 1 & 1,238 & 7,281 & 7,281 \\
\hline 2 & 1,162 & 6,835 & 14,116 \\
\hline 3 & 1,082 & 6,363 & 20,478 \\
\hline 4 & 1,075 & 6,321 & 26,799 \\
\hline 5 & 1,060 & 6,235 & 33,034 \\
\hline 6 & 1,060 & 6,235 & 39,270 \\
\hline 7 & 1,060 & 6,235 & 45,505 \\
\hline 8 & 1,060 & 6,235 & 51,740 \\
\hline 9 & 1,043 & 6,137 & 57,878 \\
\hline 10 & 1,039 & 6,113 & 63,991 \\
\hline 11 & 1,025 & 6,032 & 70,023 \\
\hline 12 & 1,019 & 5,995 & 76,018 \\
\hline 13 & 1,019 & 5,995 & 82,014 \\
\hline 14 & 1,019 & 5,995 & 88,009 \\
\hline 15 & 1,019 & 5,995 & 94,005 \\
\hline 16 & 1,019 & 5,995 & 100,000 \\
\hline 17 & $\begin{array}{c}9,572 \mathrm{E}- \\
016\end{array}$ & 5,631E-015 & 100,000 \\
\hline
\end{tabular}

From Table 3. there are 16 components that have an eigenvalue above one, which means that 16 factors are formed that are most considered. 
Volume 03 Number 01 September 2019

\section{Matrix component}

Table 4. Results of Grouping Factors Based on Component Matrix in Government

\begin{tabular}{|c|c|c|}
\hline Factor & $\begin{array}{l}\mid \text { Factor } \\
\text { Loading }\end{array}$ & $\begin{array}{c}\text { Factor } \\
\text { Identification }\end{array}$ \\
\hline Design changes occur & 0,790 & Factor 2 \\
\hline Delays in material delivery & 0,791 & Factor 8 \\
\hline Equipment delivery delays & 0,743 & Factor 17 \\
\hline Lack of coordination with related parties & 0,375 & Factor 13 \\
\hline $\begin{array}{l}\text { The method of implementation is not } \\
\text { appropriate }\end{array}$ & 0,765 & Factor 18 \\
\hline Lack of workforce & 0,650 & Factor 12 \\
\hline Lack of expertise & 0,848 & Factor 4 \\
\hline Inadequate oversight function & 0,625 & Factor 16 \\
\hline Changing extreme weather & 0,704 & Factor 7 \\
\hline Heavy / heavy rainfall & 0,986 & Factor 1 \\
\hline $\begin{array}{c}\text { The difficulty of getting materials according } \\
\text { to specifications on the market }\end{array}$ & 0,650 & Factor 8 \\
\hline Material prices are too expensive & 0,672 & Factor 14 \\
\hline Material approval & 0,863 & Factor 15 \\
\hline Delays in licensing from Satlantas & 0,418 & Factor 9 \\
\hline Lack of maximum project supervision & 0,517 & Factor 10 \\
\hline Design error from the consultant planner & 0,365 & Factor 5 \\
\hline $\begin{array}{c}\text { Communication between workers and } \\
\text { superiors is lacking }\end{array}$ & 0,650 & Factor 11 \\
\hline $\begin{array}{c}\text { Duration of delivery of goods and } \\
\text { equipment "imported }\end{array}$ & 0,817 & Factor 3 \\
\hline $\begin{array}{l}\text { The river which is near the construction, is } \\
\text { also a factor for transporting goods so it is } \\
\text { difficult during the rainy season }\end{array}$ & 0,854 & Factor 6 \\
\hline
\end{tabular}

(Source, Analysis Results 2020)

From this government matrix component, the results of the first analysis are high rainfall / heavy loading factor value with $0.986>0.5$, the observed factors are $5.867 \%$, the second factor changes the design, the loading factor value is $0.790>0.5$, the observed factor is $5.753 \%$, the third factor is the delivery time of imported goods and equipment, the loading factor value is $0.817>0.5$, the observed factor is $5.753 \%$, the 
Volume 03 Number 01 September 2019

fourth factor is the lack of power, the loading factor value is $0.848>0,5$, the observed factor of $5.753 \%$ is all the things that cause delays in the construction project.

Table 5. Results of Grouping Factors Based on Component Matrix in Private Sector

\begin{tabular}{|c|c|c|}
\hline Factor & |Factor Loading| & $\begin{array}{c}\text { Factor } \\
\text { Identification }\end{array}$ \\
\hline Unclear scope of work & 0,721 & Factor 10 \\
\hline $\begin{array}{l}\text { Unclear material specifications in } \\
\text { the contract }\end{array}$ & 0,694 & Factor 6 \\
\hline Lack of expertise & 0,724 & Factor 5 \\
\hline Lack of workforce involved & 0,552 & Factor 7 \\
\hline Late delivery of goods & 0,587 & Factor 5 \\
\hline Reduced amount of equipment & 0,644 & Factor 14 \\
\hline $\begin{array}{l}\text { Lack of information on site } \\
\text { conditions resulting in incorrect work } \\
\text { methods }\end{array}$ & 0,738 & Factor 13 \\
\hline High rainfall intensity & 0,920 & Factor 1 \\
\hline Equipment delivery delays & 0,618 & Factor 12 \\
\hline Material prices are too expensive & 0,735 & Factor 3 \\
\hline Incorrect material calculation & 0,609 & Factor 16 \\
\hline Poor or productive equipment & 0,553 & Factor 15 \\
\hline $\begin{array}{l}\text { The location is quite far from the } \\
\text { central material purchase }\end{array}$ & 0,371 & Factor 11 \\
\hline $\begin{array}{l}\text { The location is used as a } \\
\text { transportation route }\end{array}$ & 0,632 & Factor 9 \\
\hline $\begin{array}{l}\text { Materials that fit the specifications } \\
\text { are hard to find in the market }\end{array}$ & 0,756 & Factor 8 \\
\hline Slow thawing & 0,801 & Factor 2 \\
\hline $\begin{array}{l}\text { Changes in design due to adjusting } \\
\text { conditions in the field }\end{array}$ & 0,603 & Factor 4 \\
\hline
\end{tabular}

(Source, Analysis Results 2020)

From the component matrix table in the private sector, the first factor that causes delays in the private sector is high rainfall intensity, factor loading value of $0.920>0.5$, is able to explain the diversity of variants, the factor of observation is $7.281 \%$, the second factor is slow disbursement, has a loading value of $0.801>0.5$ this factor is observed at $6.835 \%$, the third factor is the material price is too expensive, has a loading factor value of $0.735>0.5$ and is able to explain the diversity of variants, the 
Volume 03 Number 01 September 2019

factor observed is $6.362 \%$, the fourth factor is a design change due to conditions in the field, having a loading factor value of $0.603>0.5$, an observed factor of $6.321 \%$.

\section{Discussion}

From some data that was done in the field, there were factors that influenced the delay. Weather factors become the dominant factor in both sectors in both government and private projects. This research is a qualitative study, where research continues and researchers try to divert information further by asking the informants for opinions about this weather factor. The most significant factors influence the completion of government and private projects as well as the differences between the factors that influence the delay of government and private projects seen from the perception of service providers and users. In analyzing the factors that cause project delays, data collection is carried out in the form of surveys through the distribution of questionnaires both from service providers and service users.

In addition to weather factors, there are other dominant factors in government projects, namely labor and private projects are the material factors that dominate and the next influence is the design factor, which is the change in design.

\section{Identify the Role of Government Regulations}

In the 101st RDTL 2014 Specifications service providers require submitting work results on time as the initial agreement, if late in submission, the building has not been completed in a timely manner then the service provider must compensate according to the initial contract agreement. If the fine has to be paid for delays in the project, then the fine will be charged in accordance with the book or the initial work contract between the goods / service provider.

\section{Identification of the Role of Employment Contracts}

Payments must be adjusted for deductions for prepayment and retention. The entrepreneur must pay the contractor the amount certified by the project manager within 28 days from the date of each certificate. if the employer makes late payments, the contractor must be paid interest on late payments in subsequent payments. interest will be calculated from the date of payment should be made until the date on which the late payment is made until the date when the late payment is made at the interest rate that was previously in force for commercial loans for each currency where the payment was made.

\section{CONCLUSIONS}

1. This study found several dominant factors affecting the delay of the Bidau TimorLeste bridge construction project, including the types of weather, material and financial factors.

2. To anticipate delays in construction projects a work contract needs to be carried out in accordance with the contract law in which all matters are regulated in it, so that for anticipation, mitigation and accountability are clear.

3. Identification of the application of delays in handling the Bidau Timor-Leste bridge construction project if viewed from the side of the existing contract there are still shortcomings, so it needs to be improved in terms of working contract documents and refer to the contract law. 
Volume 03 Number 01 September 2019

\section{REFERENCES}

Andi, E. (2003). Factot-the potential factor that can affect the construction time consisting of seven (7) categories. University of Petra

Bungin, B. (2004). Qualitative research.

C. Yuliana, "Analysis of causal factors in the implementation of the bridge development project," technique. Civil, Vol. 14, No. 2, Pp. 114 - 125, 2013.

F. Kurniawan, D. A. R. Wulandari, and L. A. Ayu, " Case Studies delay construction project in East Java province based on the contract of employment, "Narotama J. Tek. Civil, vol. 2, No. 2, pp. 21 - 31, 2018.

E. Simanjuntak and Syahrizal, " BRIDGES (Case study: construction project of Kuala Tanjung high-speed RAILWAY bridge), "Dep. Tech. Civil, Univ. of North Sumatera, No. 1, pp. $1-9,2015$.

J. U. D. Hatmoko and F. Kistiani, " Risk simulation Model of the Material supply chain construction project, "Komun Media. Tech. Civil, vol. 23, No. 1, p. 1, 2017, doi: 10.14710/mkts. v23i 1.14697.

Joni, I. G. P. (2014). Causes of bridge structure failure factors.

Messah, Y., Lazry, H., \& Dantje, A. (2013). Control of time and cost of construction work as a impact of design change. Journal of Civil Engineering.

S. E. Bawono, "Identification of failure to implement Crash Program," vol. XIII, No. $1,2017$.

Sugiono. (2009). Quantitative and qualitative approach of R. D. Bandung: Alfa Beta. 